\title{
A COMPREHENSIVE REVIEW ON THE ASIAN PLANTS UTILISED IN STRESS-RELATED DISORDERS
}

\author{
FAUZIAHANIM ZAKARIA ${ }^{1 *}$ AND HAFANDI AHMAD ${ }^{2}$ \\ ${ }^{1}$ School of Pharmaceutical Sciences, Universiti Sains Malaysia, Pulau Pinang, Malaysia \\ ${ }^{2}$ Faculty of Veterinary Medicine, Universiti Putra Malaysia, Selangor, Malaysia
}

Published online: 24 May 2021

To cite this article: FAUZIAHANIM ZAKARIA \& HAFANDI AHMAD (2021) A comprehensive review on the Asian plants utilised in stress-related disorders, Malaysian Journal of Pharmaceutical Sciences, 19(1): 77-96, https://doi.org/10.21315/mjps2021.19.1.6 To link to this article: https://doi.org/10.21315/mjps2021.19.1.6

\begin{abstract}
Asian countries are reckoned for their vast plant-rich regions with a long history of traditional medicine that spans approximately 6,500 years. Asian people inherit knowledge from their ancestors about the use of the surrounding plants to treat many infirmities and diseases, including stress-related disorders such as anxiety and depression. As such, this review provides an ethnopharmacological and phytochemical overview of Asian plants with high antistress potential. This review serves as a baseline for the discovery of new and potent antidepressants. Articles from 2007 to 2020 were reviewed extensively using Google Scholar and Scopus search engines based on the following keywords: 'antidepressant AND Asia AND plants', 'anxiolytic AND Asia AND plants', as well as 'antistress AND Asia AND plants'. In total, 71 Asian plants were documented. Most of the plants were reported from India (36\%) and followed by China (31\%). Other countries, including Japan, Bangladesh, Thailand, Pakistan, Korea, Taiwan and Algeria, have published several reports regarding local plants with antidepression potential. As a result, 15 pure compounds isolated from these plants displayed antidepressive potential.
\end{abstract}

Keywords: Major depressive disorder, Phytochemistry, Anxiolytic, Stress, Asia

\section{INTRODUCTION}

The past few decades have witnessed a vast increase in studies concerning plant-based antidepressants. Depression refers to a complex and disabling psychiatric disorder that has affected an estimated $21 \%$ of the world population. Depression has been projected to be the leading cause of disability by 2030 . This disorder is a type of neurodegenerative disease linked with persistent low mood and anhedonia (Qiong et al. 2009). Depression refers to a significant disorder across all ages that demands a significant amount of time and money for treatment. Although synthetic antidepressant drugs are easily available and can effectively

"Corresponding author: fauziahanimz@usm.my

(C) Penerbit Universiti Sains Malaysia, 2021. This work is licensed under the terms of the Creative Commons Attribution (CC BY) (http://creativecommons.org/licenses/by/4.0/). 
treat clinically-depressed patients, such drugs have been noted for their adverse effects that often compromise the therapeutic effects. This has sparked the emergence of alternative treatments using medicinal plants or plant-based antidepressant concomitants. Although plants are known to have potentially psychoactive effects, extensive studies are sought in alternative and complementary in vivo models to further substantiate their benefits.

Plants, apart from being a main source of food, possess a vast range of phytomedicinal properties. The practice and knowledge on the usage of plants for medicinal purposes have originated thousands of years ago. More than 20,000 species of plants have been used as traditional medicine worldwide with potential reservoirs for the discovery of new drugs. Historical Greek/Roman knowledge on the use of using plant extracts was further expanded as an Arabic medicinal art established by lbn Sina (known as Avicenna, 980-1,037) in his book entitled Qanun. This book refers to one of the most influential references used for drug-plant therapeutics after it was translated from Arabic to Latin (Zenk and Juenger 2007). Qanun's materia medica lists 760 drugs, along with their applications and efficacy. Qanun has served as a reference for almost a millennium to date (Zenk and Juenger 2007).

\section{METHODS}

Online bibliographical databases, such as Scopus and Google Scholar, were used to investigate published papers relevant to the topic at hand. These articles were retrieved using several keywords, including 'antidepressant AND Asia AND plants', 'anxiolytic AND Asia AND plants', as well as 'antistress AND Asia AND plants'. The papers were limited to those published between 2007 and 2020. The articles selected for this review included plants (i) native to Asian regions with wide distribution; (ii) traditionally used in Asia for antidepressant and anxiolytic treatments; only plants with ethnopharmacological evidence for antidepressant and anxiolytic local uses were selected; (iii) reported to have in vitro and in vivo antidepressant and anxiolytic activities; (iv) observed for pure active antidepressant and anxiolytic constituents isolated or classes of compounds identified, and (v) with toxic effects on living systems. A plant database called 'Plant list' was applied for taxonomic correction of all the documented plant species (Tropicos 2021). The structures of therapeutically active antidepressant and anxiolytic chemical compounds were developed by using ACDLab freeware 2015 software. The information is summarised in Tables 1 to 3 and Figures 1 and 2 for clearer observation. 


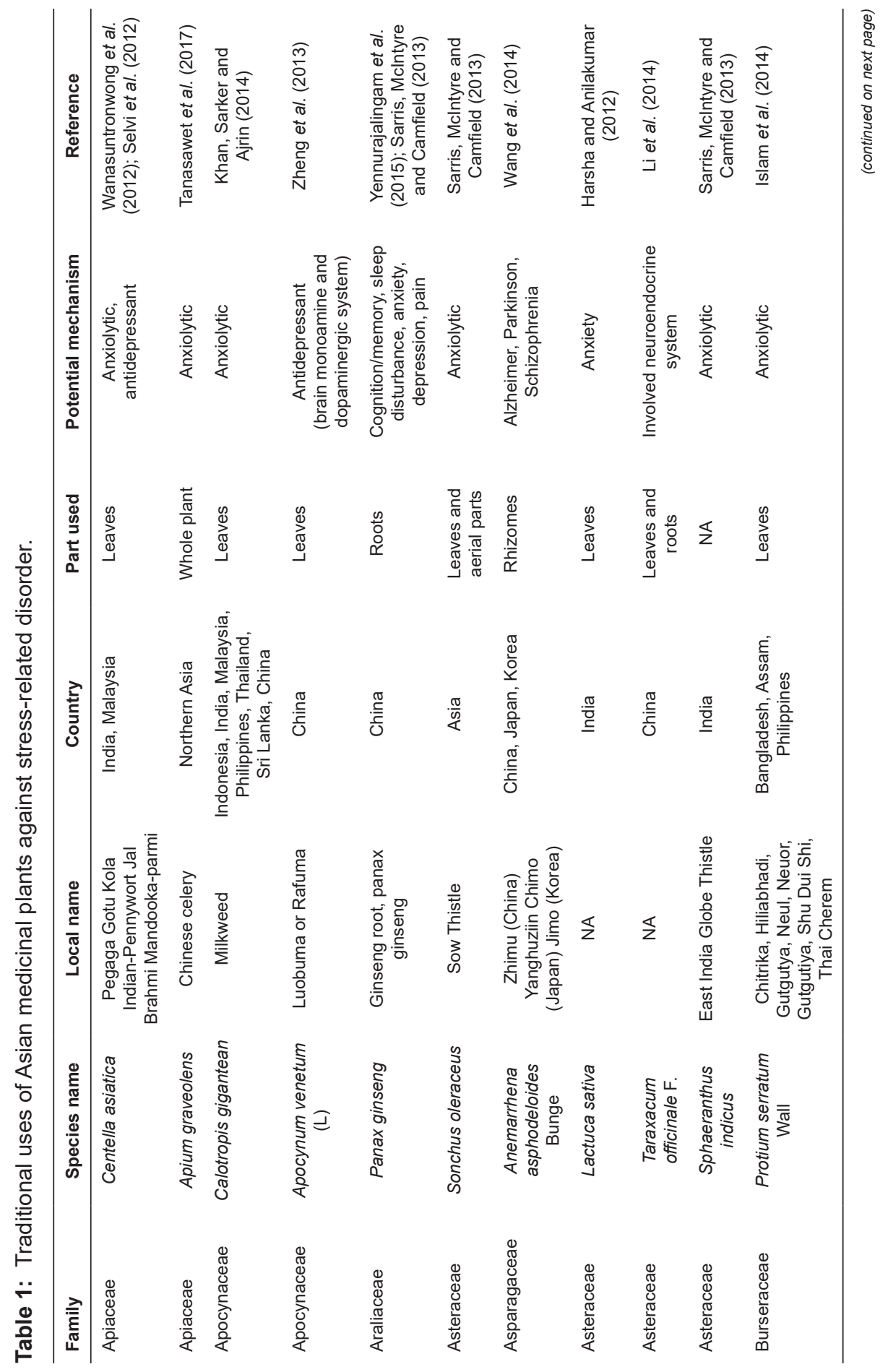

Malay J Pharm Sci, Vol. 19, No. 1 (2021): 77-96 


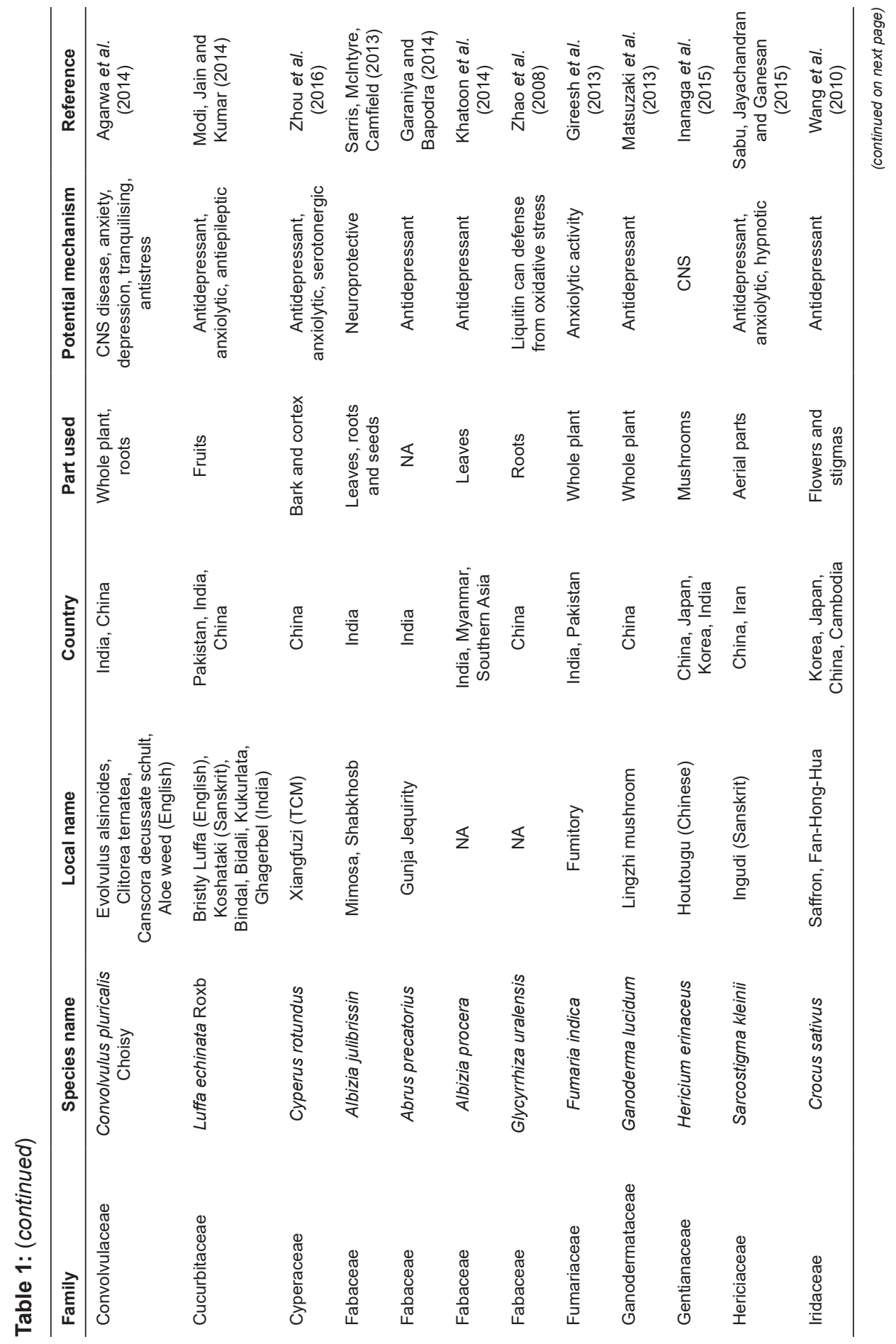

Malay J Pharm Sci, Vol. 19, No. 1 (2021): 77-96 


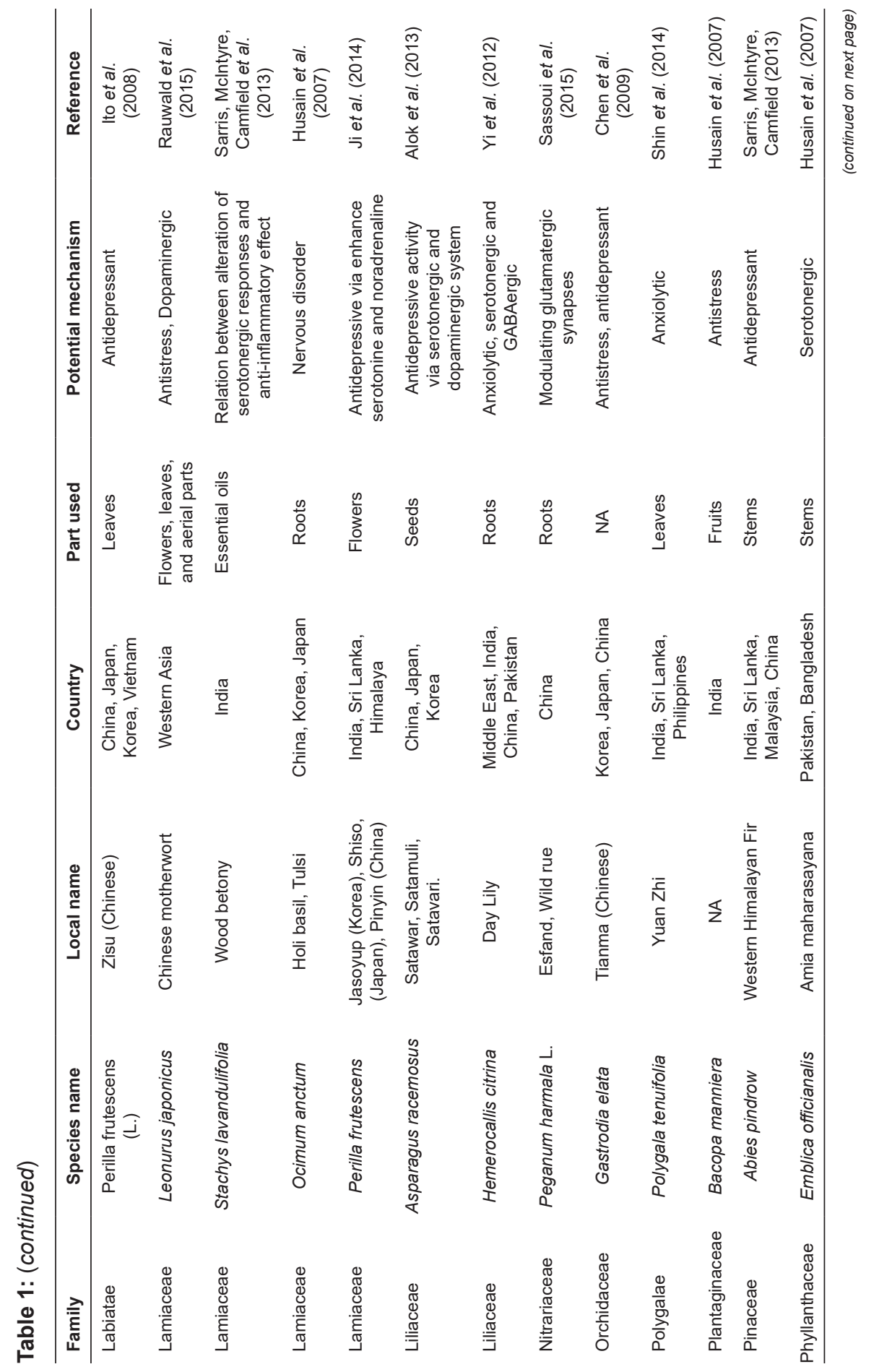




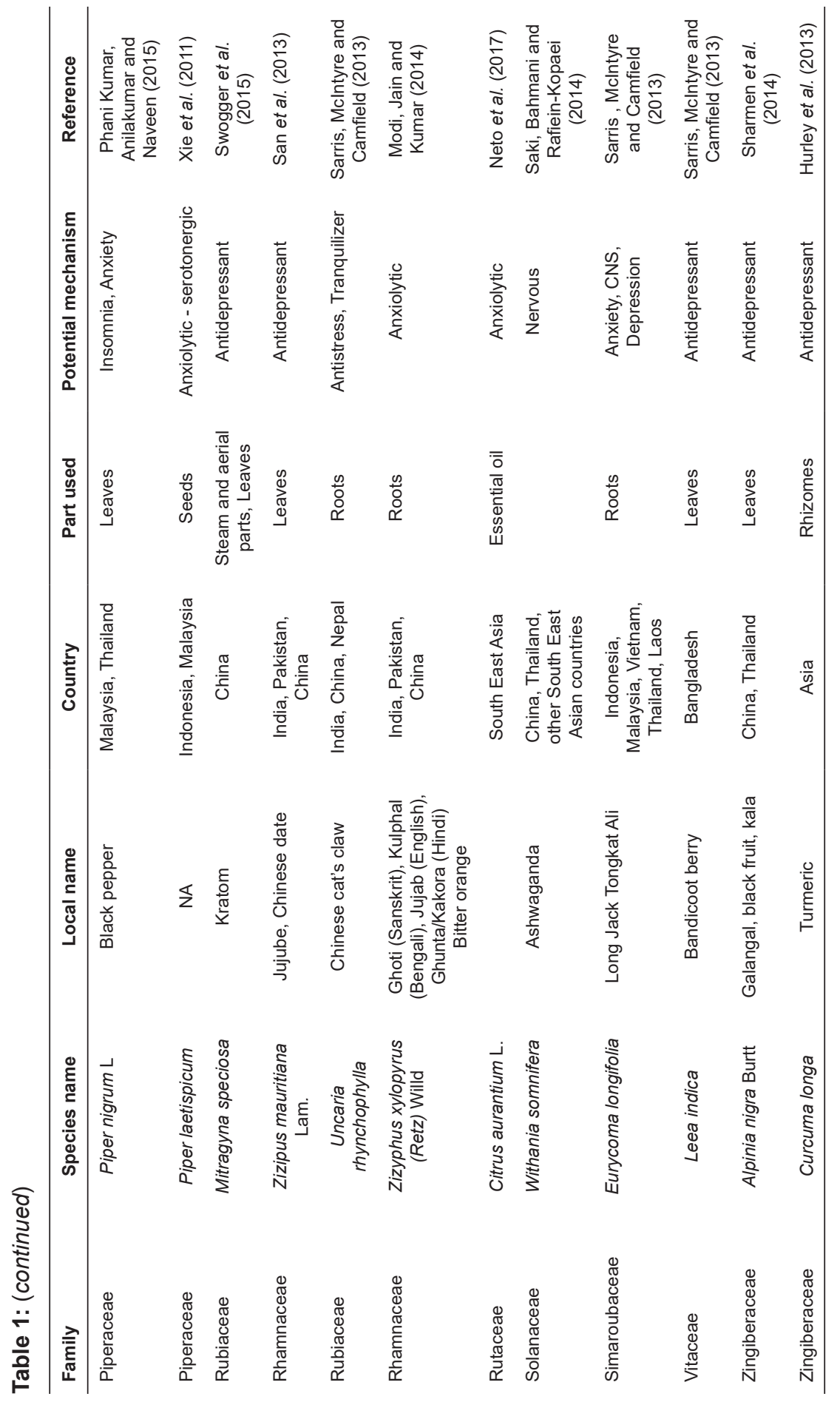

Malay J Pharm Sci, Vol. 19, No. 1 (2021): 77-96 


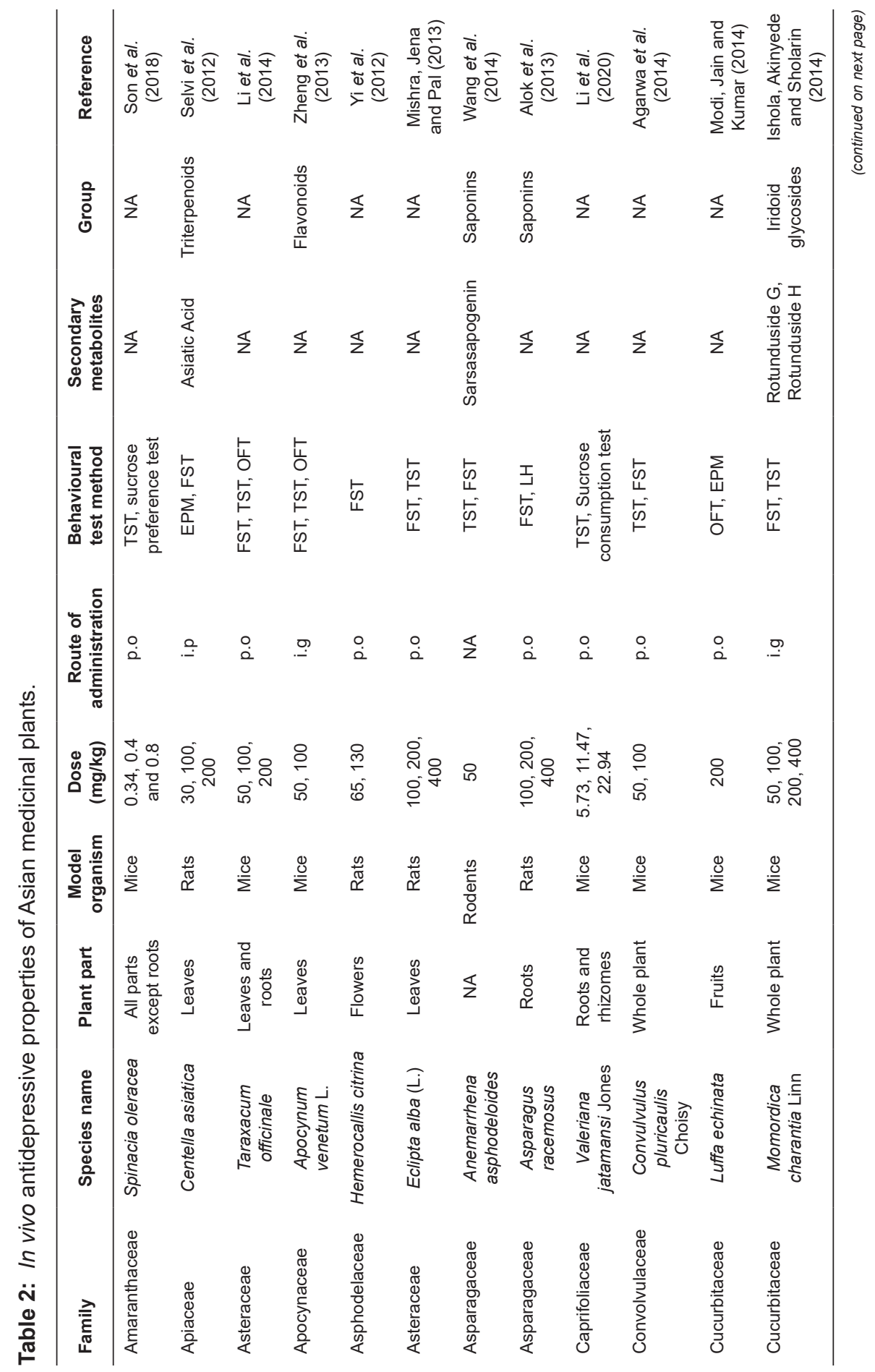

Malay J Pharm Sci, Vol. 19, No. 1 (2021): 77-96 


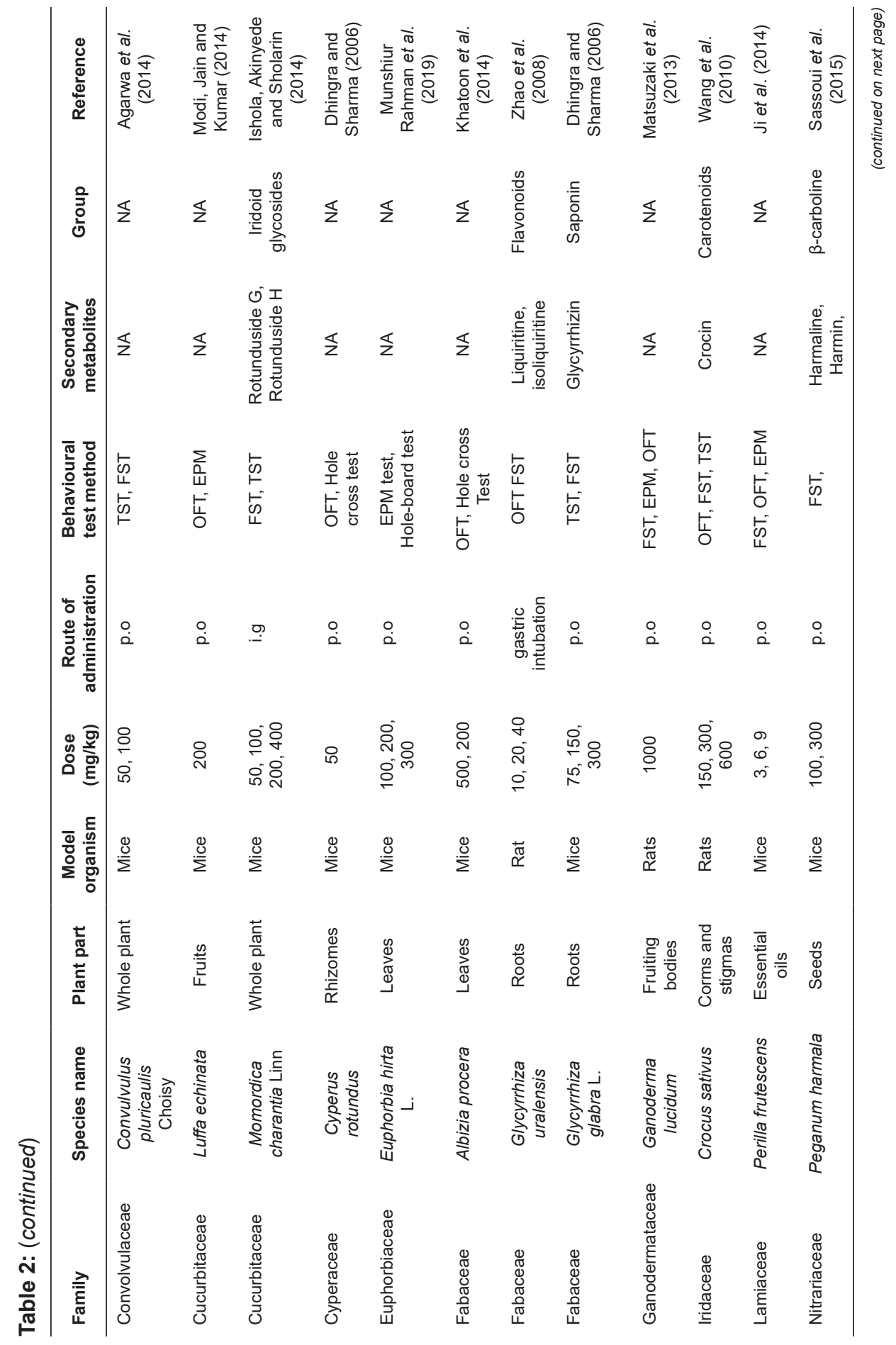

Malay J Pharm Sci, Vol. 19, No. 1 (2021): 77-96 


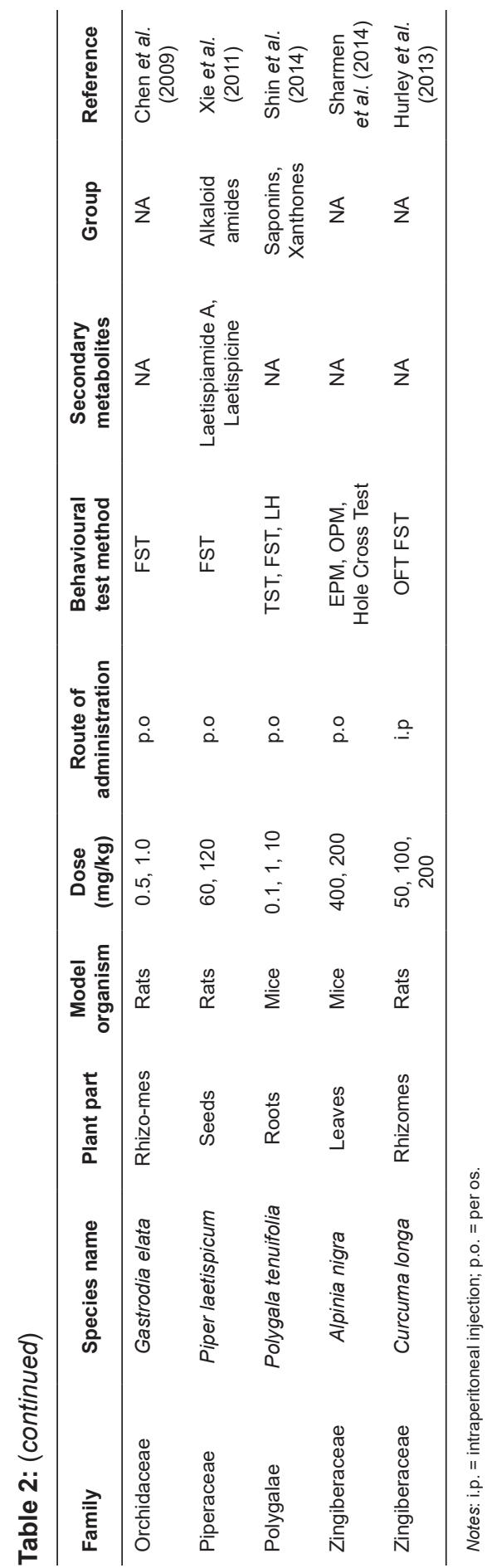

Malay J Pharm Sci, Vol. 19, No. 1 (2021): 77-96 


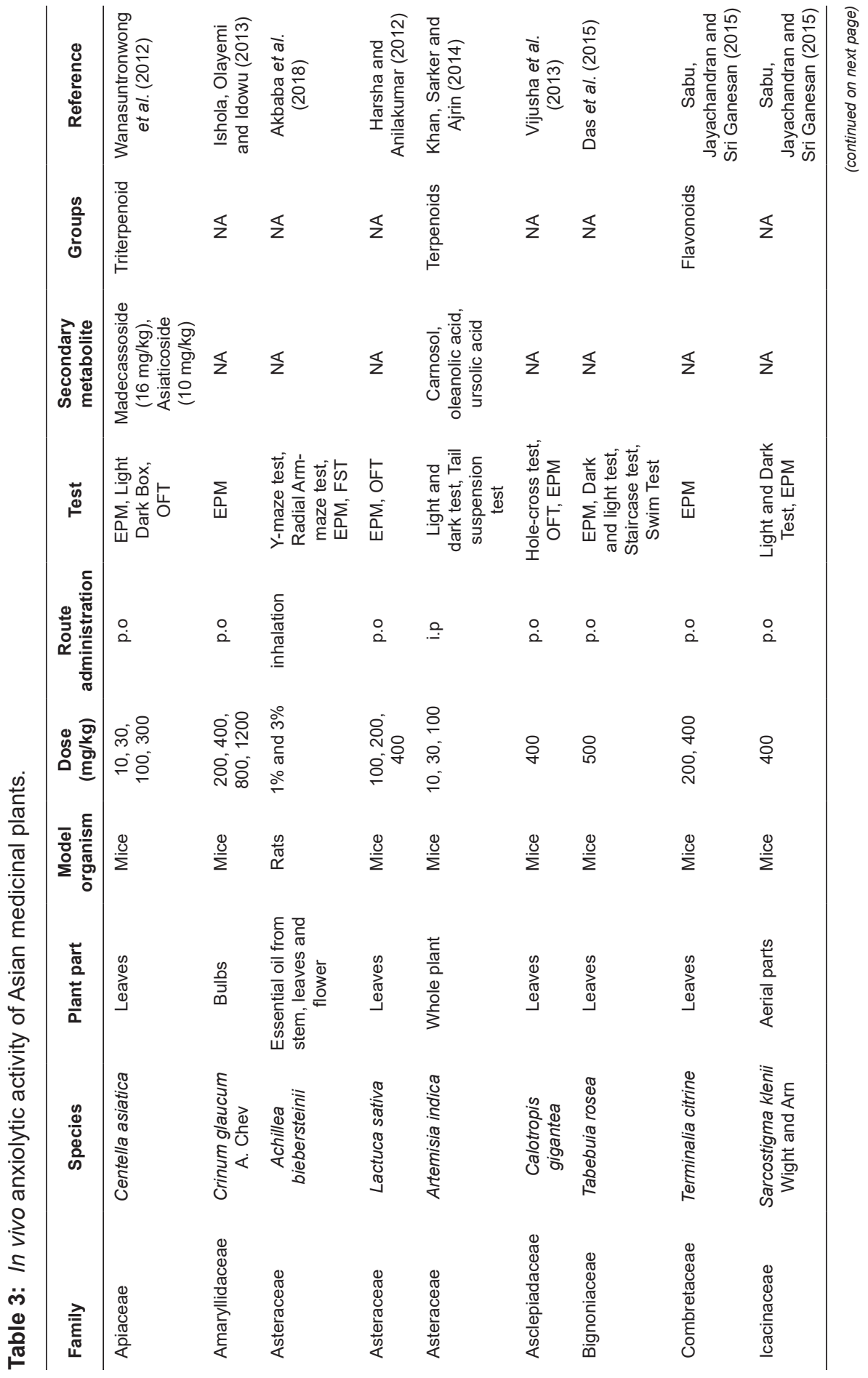

Malay J Pharm Sci, Vol. 19, No. 1 (2021): 77-96 


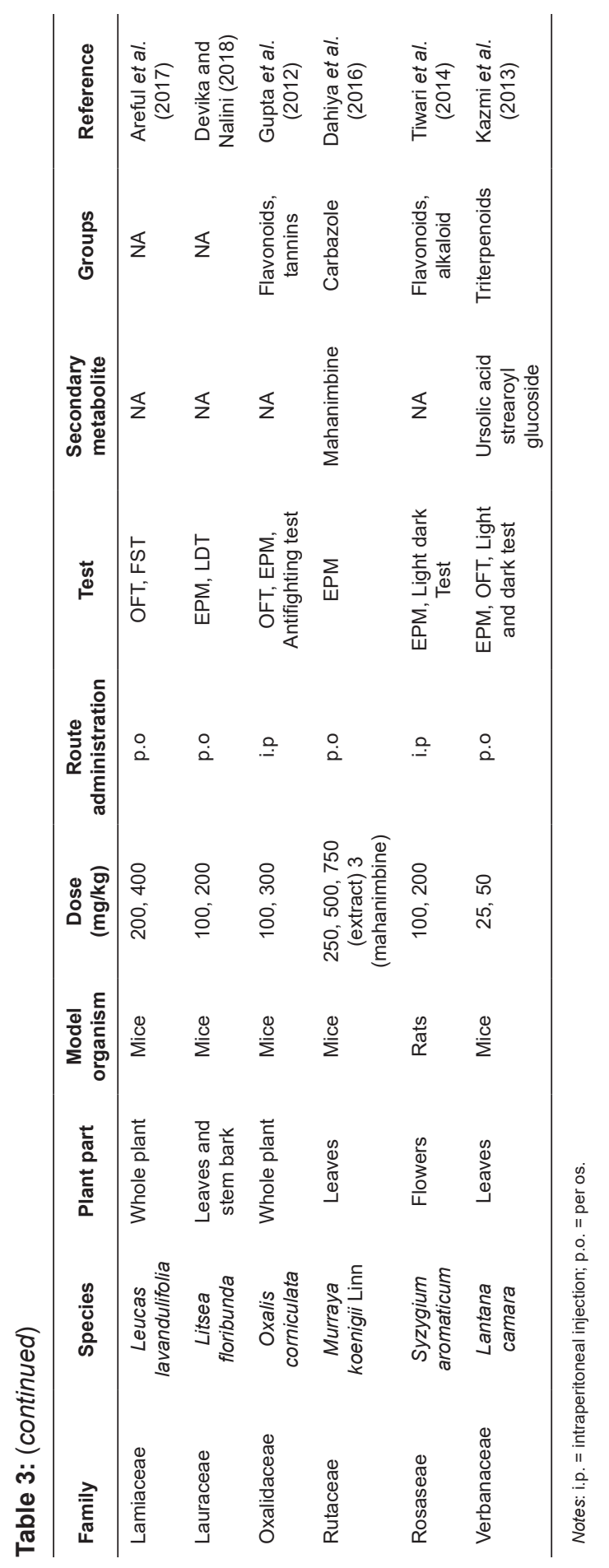

Malay J Pharm Sci, Vol. 19, No. 1 (2021): 77-96 
Reported species of plants having anti-stress

related potential in Asia countries.

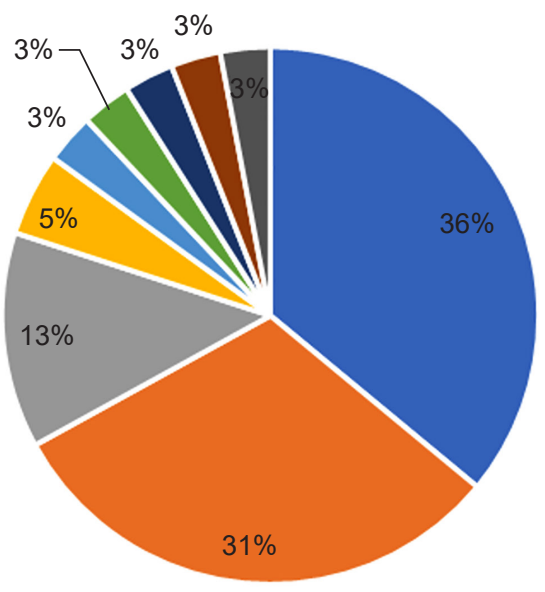

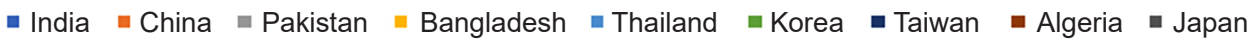

Figure 1: Distribution of Asian plants species having potential antistress-related disorder activity.

*These data are only based on literature from Scopus and Google scholar on monotherapy preparation.
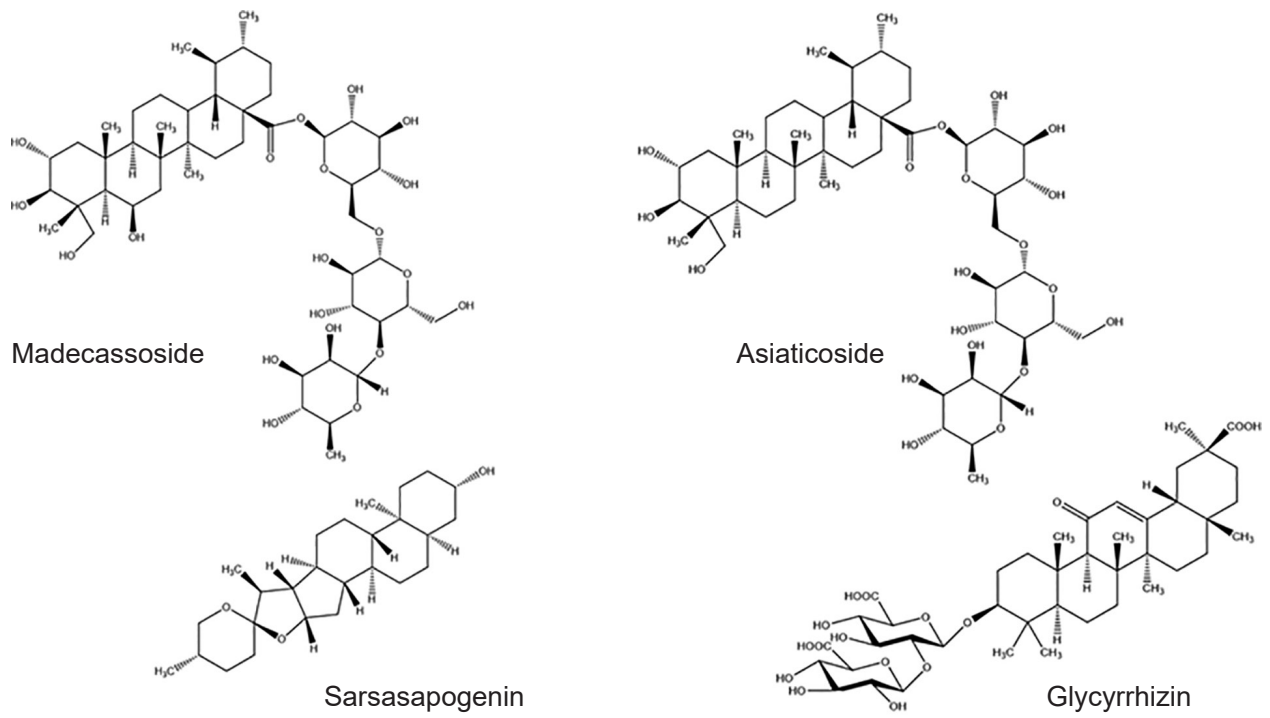

Figure 2: Triterpenoid/Saponins compounds have potential antistress-related disorder activity. 


\section{Asian Antistress-Related Plants}

The variations in climate, ecological, geographical, physiographical and topographical conditions are some of the core reasons on the vast diversity of plant growth within the Asian region (Tariq, Mussarat and Adnan 2015). A total of 71 Asian medicinal plants were reviewed in this article. Some plants appear to be endemic worldwide, while others are native to this region. The distribution of Asian plants species having potential antistressrelated activity was summarised in Figure 1. Eight species of anxiolytic plants were reported from India and followed by two each from Bangladesh, Thailand and Pakistan. Eleven species of plants with antidepressive potential were reported from China, five from India, and one each from Bangladesh, Korea, Taiwan, Algeria and Japan. Some plants have been applied in monotherapy treatment alone, while others for multi-therapy treatment. Some plants, such as Centella asiatica (44) and (68) Convolvulus pluricaulis Choisy (14) and (52), Leonurus japonicas (26) and Albizia julibrissin (9), seemed to possess both anxiolytic and antidepressant potential. Most of these plants can be found in other parts of the world, such as Africa, America and Europe.

\section{Depression and Ethnomedicinal Plants}

Asian elderly are familiar with plants that can be utilised to treat a vast range of diseases, including stress-related disorders such as anxiety and depression. In this review, 71 plant species from 59 families have been traditionally applied to treat stress-related conditions. The Asteraceae, Fabaceae and Lamiaceae families comprise of four species (13.3\%), while Apocynaceae, Liliaceae, Piperaceae, Rubiaceae and Zingiberaceae with two species each contribute to $10 \%$ of the list of plant species. Nevertheless, studies on pure constituents that equip these plants with antistress properties are in scarcity. Most of the studies have reported attributes of antistress properties in terms of flavonoids (Zheng et al. 2013; Zhao et al. 2008; Das et al. 2015; Gupta et al. 2012 and Tiwari et al. 2014), triterpenoids or saponins (Selvi et al. 2012; Wang et al. 2014; Alok et al. 2013; Shin et al. 2014; Wanasuntronwong et al. 2012; Khan et al. 2016; Kazmi et al. 2013) and alkaloids (Xie et al. 2011; Tiwari et al. 2014). Examples of constituents that have potential antistress-related activity were presented in Figure 2.

Most plants have been used in monotherapy, while only a handful of studies have probed into multiple ethnomedicinal therapies (mixing two or more plants) to treat stressrelated and depression disorders. For instance, three Chinese herbs, namely, Rhizome Chuanxiong, Radix Scutellaria and Radix Phellodendri, were evaluated in vitro to assess their neuroproliferation-promoting potential in vitro and followed by in vivo study by using an experimental setting of chronic mild stress (CMS) for 14 days. Another popular traditional Chinese medicine that has been used to treat stress-related disorders in Japan, Korea and China is Kami-Shoyo-San, which is a combination of nine plants for therapy purposes (Park et al. 2007).

\section{Clinical Study of Antistress-Related Disorder Activity Plants}

Antistress-related activity displayed by plants has been noted since ages ago. A survey was carried out in Taiwan to study the prescription patterns of Chinese herbal products among patients with sleep and depression disorders. Out of 11,571 patients, 11,389 used Western medication, 131 used Chinese herbal formula, while 77 used both Western and Chinese herbal medications (Chen et al. 2015). A number of studies revealed that the constituents 
of Asian plants have indeed been used in clinical studies. One of these studies refers to the use of Nepeta menthoides Boiss \& Buhse aqueous extract to evaluate the antidepressant properties of the plant, along with its side effects to human (Chen et al. 2015).

Meanwhile, several studies had adopted the in vitro analysis. For instance, a study used the ischaemia-hypoxia cell model. After the cells were treated with $10 \mathrm{nmol} / \mathrm{L}$ and 100 $\mathrm{nmol} / \mathrm{L}$ of Asiaticoside extracted from Centella asiatica, a significant increase was observed in the survival rate of the cells (Sun, Liu and Li 2015). Nonetheless, behavioural studies are being sought to assess mood disorders.

\section{CONCLUSION}

The diverse plant species native to the Asian region are renowned for its valuable and irreplaceable assets. These plants possess medicinal values for the treatment of stressrelated disorders. Although roots and leaves are mostly applied for ethnomedicinal preparation, it is noteworthy to highlight that root harvesting may be destructive. Therefore, care must be taken to avoid exploiting these plants. Some information, such as method of preparation, dosage of ethnomedicine and method of administration, has been excluded from the review. Knowledge pertaining to the mechanism of action of these medicinal plants is still in its infancy phase. This calls for further exploration within this subject matter for the discovery of a potent antidepressant.

\section{REFERENCES}

AGARWA, P., SHARMA, B., FATIMA, A. \& JAIN, S. K. (2014) An update on Ayurvedic herb Convolvulus pluricaulis Choisy, Asian Pacific Journal of Tropical Biomedicine, 4(3): 245-252. https://doi.org/10.1016/S2221-1691(14)60240-9

AKBABA, E., HASSAN. S., SUR, T. M. \& BAGCI, E. (2018) Memory enhancing, anxiolytic and antidepressant effects of Achillea biebersteinii (Asteraceae) essential oil on scopolamineinduced rats, Journal of Essential Oil Bearing Plants, 21(3): 825-839. https://doi.org/10 .1080/0972060X.2018.1483741

ALOK, S., JAIN, S. K., VERMA, A., KUMAR, M., MAHOR, A. \& SABHARWAL, M. (2013) Plant profile, phytochemistry and pharmacology of Asparagus racemosus (Shatavari): A review, Asian Pacific Journal of Tropical Disease, 3(3): 242-251. https://doi.org/10.1016/ S2222-1808(13)60049-3

AREFUL, I., HUSSAIN, M. S., SEN, N., ABEDIN, F., MILLAT, M. S., ISLAM, M. S., et al. (2017) Investigation of in vitro thrombolytic and anti-helminthic activity and in vivo anxiolytic and antidepressant potentiality with phytochemical nature of methanolic extract of Leucas lavandulifolia, Sustainable Chemistry and Pharmacy, 6: 61-66. https://doi.org/10.1016/j. scp.2017.09.001

CHEN, P. -J., HSIEH, C. -L., SU, K. -P., HOU, Y. -C., CHIANG, H. -M. \& SHEEN, L. -Y. (2009) Rhizomes of Gastrodia elata $B_{L}$ possess antidepressant-like effect via monoamine modulation in subchronic animal model, The American Journal of Chinese Medicine, 37(6): 1113-1124. https://doi.org/10.1142/S0192415X09007533

Malay J Pharm Sci, Vol. 19, No. 1 (2021): 77-96 
CHEN, Y. -L., LEE, C. -Y., HUANG, K. -H., KUAN, Y. -H. \& CHEN, M. (2015) Prescription patterns of Chinese herbal products for patients with sleep disorder and major depressive disorder in Taiwan, Journal of Ethnopharmacology, (171): 307-316. https://doi.org/10.1016/ j.jep.2015.05.045

DAHIYA, J., SINGH, J., KUMAR, A. \& SHARMA, A. (2016) Isolation, characterisation and quantification of an anxiolytic constituent - mahanimbine, from Murraya koenigii Linn. spreng leaves, Journal of Ethnopharmacology, 193: 706-711. https://doi.org/10.1016/j. jep.2016.10.014

DAS, N., GOSHWAMI, D., HASAN, M. S., MAHMUD Z. A., RAIHAN, S. Z. \& SULTAN, M. Z. (2015) Evaluation of antinociceptive, anti-inflammatory and anxiolytic activities of methanolic extract of Terminalia citrina leaves, Asian Pacific Journal of Tropical Disease, 5(Suppl 1): S137-S141. https://doi.org/10.1016/S2222-1808(15)60875-1

DEVIKA, M. \& NALINI, M. S. (2018) Evaluation of antidepressant of Litsea floribunda (BL.) Gamble — Lauraceae using animal models, International Journal of Pharmaceutical Sciences and Research, 37: 3427-3432. https://doi.org/0.13040/IJPSR.0975-8232.9(8).3427-32

DHINGRA, D. \& SHARMA, A. (2006) Antidepressant-like activity of Glycyrrhiza glabra L. in mouse models of immobility tests, Progress in Neuro-Psychopharmacology and Biological Psychiatry, 30(3): 449-454. https://doi.org/10.1016/j.pnpbp.2005.11.019

GARANIYA, N. \& BAPODRA, A. (2014) Ethnobotanical and phytopharmacological potential of Abrus precatorius L.: A review, Asian Pacific Journal of Tropical Biomedicine, 4(Suppl 1): S27-S34. https://doi.org/10.12980/APJTB.4.2014C1069

GIREESH, K. H., SUDIR, K. C., GEETA, R., SHYAM, S. C. \& KUMAR, V. (2013) Potential antianxiety activity of Fumaria indica: A preclinical study, Pharmacognosy Magazine, 9(33): $1-9$.

GUPTA, G., KAZMI, I., AFZAL, M., RAHMAN, M. \& ANWAR, F. (2012) Anxiolytic effect of Oxalis corniculate (Oxalidaceae) in mice, Asian Pacific Journal of Tropical Disease, 2(Suppl 2): S837-S840. https://doi.org/10.1016/S2222-1808(12)60275-8

HARSHA, S. N. \& ANILAKUMAR, K. R. (2012) Effects of Lactuca sativa extract on exploratory behavior pattern, locomotor activity and anxiety mice, Asian Pacific of Tropical Medicine, 2(Suppl 1): S475-S479.

HURLEY, L. L., AKINFIRESOYE, L., NWULIA, E., KAMIYA, A., KULKARNI, A. A. \& TIZABI, Y. (2013) Antidepressant-like effects of curcumin in WKY rat model of depression is associated with an increase in hippocampal BDNF, Behavioural Brain Research, 239(1): 27-30. https://doi.org/10.1016/j.bbr.2012.10.049

HUSAIN, G. M., MISHRA, D., SINGH, P. N., RAO, C. V. \& KUMAR, V. (2007) Ethnopharmacological review of native traditional medicinal plants for brain disorders, Pharmacognosy Review, 1(1): 19-28. 
INANAGA, K., YOSHIDA, M., TOMITA, O. \& UCHIMURA, N. (2015) Treatment of mild neurocognitive disorder with compounds from Hericium erinacium, International Medical Journal, 22(3): 152-153.

ISHOLA, I. O., AKINYEDE, A. A. \& SHOLARIN, A. M. (2014) Antidepressant and anxiolytic properties of the methanolic extract of Momordica charantia Linn (Cucurbitaceae) and its mechanism of action, Drug Research, 64(7): 368-376. https://doi. org/10.1055/s-0033-1358712

ISHOLA, I. O., OLAYEMI, S. O. \& IDOWU, A. R. (2013) Anticonvulsant, anxiolytic and hypnotic effects of aqueous bulb extract of Crinum glaucum A. Chev (Amaryllidaceae): Role of GABAergic and nitrergic systems, Pakistan Journal of Biological Science, 16(15): $701-$ 710. https://doi.org/10.3923/pjbs.2013.701.710

ISLAM, M. R., KABIR, M. F., ALAM, R., DHAR, R., RANA, M. N., ISLAM, M. E., et al. (2014) Sedative, membrane stability, cytotoxic and antioxidant properties of methanol extract of leaves of Protium serratum wall, Asian Pacific Journal of Tropical Disease, 4(Suppl 2): S928-933. https://doi.org/10.1016/S2222-1808(14)60760-X

ITO, N., YABE, T., GAMO, Y., NAGAI, T., OIKAWA, T., YAMADA, H., et al. (2008) Rosmarinic acid from Perillae Herba produces an antidepressant-like effect in mice through cell proliferation in the hippocampus, Biological and Pharmaceutical Bulletin, 31(7): 13761380. https://doi.org/10.1248/bpb.31.1376

JI, W. W., LI, R. P., LI, M., WANG, S. Y., ZHANG, X., NIU, X. X., et al. (2014) Antidepressantlike effect of essential oil of Perilla frutescens in a chronic, unpredictable, mild stress-induced depression model mice, Chinese Journal of Natural Medicine, 12(10): 753-759. https://doi. org/10.1016/S1875-5364(14)60115-1

KAZMI, I., AFZAL, M., ALI, B., DAMANHOURI, Z. A., AHMAOL, A. \& ANWAR, F. (2013) Anxiolytic potential of ursolic acid derivative-a stearoyl glucoside isolated from Lantana camara L. (Verbanaceae), Asian Pacific Journal of Tropical Medicine, 6(6): 433-437. https://doi.org/10.1016/S1995-7645(13)60069-3

KHAN, I., KARIM, N., AHMAD, W., ABDELHALIM, A. \& CHEBIB, M. (2016) GABA-A receptor modulation and anticonvulsant, anxiolytic, and antidepressant activities of constituents from Artemisia indica Linn., Evidence-Based Complimentary and Alternative Medicine, 2016: 1-12. https://doi.org/10.1155/2016/1215393

KHAN, I. N., SARKER, M. M. I. \& AJRIN, M. (2014) Sedative and anxiolytic effects of ethanolic extract of Calotropis gigantea (Asclepiadaceae) leaves, Asian Pacific Journal of Tropical Biomedicine, 4(Suppl 1): S400-S404. https://doi.org/10.12980/APJTB.4.2014C1147

KHATOON, M. M., KHATUN, M. H., ISLAM, M. E. \& PARVIN, M. S. (2014) Analgesic, antibacterial and central nervous system depressant activities of Albizia procera leaves, Asian Pacific Journal of Tropical Biomedicine, 4(4): 279-284. https://doi.org/10.12980/ APJTB.4.2014C348 
LI, Y. -C., SHEN, J. -D., LI, Y. -Y. \& QI, H. (2014) Antidepressant effects of the water extract from Taraxacum officinale leaves and roots in mice, Pharmaceutical Biology, 52(8): 1028-1032. https://doi.org/10.3109/13880209.2013.876432

LI, Y., WU, L., CHEN, C., WANG, L., GUO, C., ZHAO, X., et al. (2020) Serum metabolic profiling reveals the antidepressive effects of the total iridoids of Valeriana jatamansi Jones on chronic unpredictable mild stress mice, Frontiers in Pharmacology, 11(338): 1-13. https://doi.org/10.3389/fphar.2020.00338

MATSUZAKI, H., SHIMIZU, Y., IWATA, N., KAMIUCHI, S., SUZUKI, F., IIZUKA, H., et al. (2013) Antidepressant-like effects of a water-soluble extract from the culture medium of Ganoderma lucidum mycelia in rats, BMC Complementary and Alternative Medicine, 13(370): 1-8. https://doi.org/10.1186/1472-6882-13-370

MISHRA, S., JENA, M. \& PAL, A. (2013) Evaluation of antidepressant activity of Eclipta alba using animal models, Asian Journal of Pharmaceutical and Clinical Research, 6(Suppl 3): 118-120.

MODI, A., JAIN, S. \& KUMAR, V. (2014) Zizyphus xylopyrus (Retz.) Willd: A review of its folkloric, phytochemical and pharmacological perspectives, Asian Pacific Journal of Tropical Disease, 4(Suppl 1): S2-S7. https://doi.org/10.1016/S2222-1808(14)60408-4

MODI, A. \& KUMAR, V. (2014) Luffa echinata Roxb. - A review on its ethnomedicinal, phytochemical and pharmacological perspective, Asian Pacific Journal of Tropical Disease, 4(Suppl 1): S7-S12. https://doi.org/10.1016/S2222-1808(14)60409-6

MUNSHIUR RAHMAN, S. M., RANA S., ISLAM, M. N., KUMER, A., HASSAN, M. M., BISWAS, T. K., et al. (2019) Evaluation of anxiolytic and sedative-like activities of methanolic extract of Euphorbia hirta leaves in mice, Pharmacology \& Pharmacy, 10: 283297. https://doi.org/10.4236/pp.2019.106023

NETO, G. C., BRAGA, J. E. F., ALVES, M. F., PORDEUS, L. C. D. M., SANTOS, S. G. D., SCOTTI, M. T., et al. (2017) Anxiolytic effect of Citrus aurantium L. in crack users, Evidence-based Complementary and Alternative Medicine, 2017: 1-8. https://doi.org/10 $.1155 / 2017 / 7217619$

PARK, S. -W., KIM, Y. -K, LEE, J. -G., KIM, S. -H., KIM, J. -M., YOON, J. -S., et al. (2007) Antidepressant-like effects of the traditional Chinese medicine kami-shoyo-san in rats, Psychiatry and Clinical Neuroscience, 61(4): 401-406. https://doi.org/10.1111/j.1440-1819 .2007.01676.x

PHANI KUMAR, G., ANILAKUMAR, K. R. \& NAVEEN, S. (2015) Phytochemical having neuroprotective properties from dietary sources and medicinal herbs, Pharmacognosy Journal, 7(1): 1-17. https://doi.org/10.5530/pj.2015.1.1

QIN, T., FANG, F., SONG, M., LI, R., MA, Z. \& MA, S. (2016) Umbelliferone reverses depression-like behavior in chronic unpredictable mild stress-induced rats by attenuating neuronal apoptosis via regulating ROCK/Akt pathway, Behavioral Brain Research, 317: 147-156. https://doi.org/10.1016/j.bbr.2016.09.039 
QIONG, L., BING, L., HAI-YAN, Z., YAN-QING, W., JIN, Y. \& GEN-CHENG, W. (2009) Clomipramine treatment reversed the glial pathology in a chronic unpredictable stressinduced rat model of depression, European Neuropsychopharmacology, 19: 796-805. https://doi.org/10.1016/j.euroneuro.2009.06.010

RAUWALD, H. W., SAVTSCHENKO, A., MERTEN, A., RUSCH, C., APPEL, K. \& KUCHTA, K. (2015) GABA A receptor binding assays of standardized Leonurus cardiaca and Leonurus japonicus extracts as well as their isolated constituents, Planta Medica, 81: 1103-1110. https://doi.org/10.1055/s-0035-1546234

SABU, N. S., JAYACHANDRAN, T. P. \& SRI GANESAN, P. (2015) Evaluation of anxiolytic activity of aerial parts of Sarcostigma kleinii Wight and Arn, Asian Journal of Pharmaceutical and Clinical Research, 8(2): 412-416.

SAKI, K., BAHMANI, M. \& RAFIEIAN-KOPAEI, M. (2014) The effect of most important medicinal plants on two important psychiatric disorders (anxiety and depression)-a review, Asian Pacific Journal of Tropical Disease, 7(Suppl 1): 34-42. https://doi.org/10.1016/ S1995-7645(14)60201-7

SAN, A. M. M., THONGPRADITCHOTE, S., SITHISARN, P. \& GRITSANAPAN, W. (2013) Total phenolics and total flavonoids contents and hypnotic effect in mice of Ziziphus mauritiana Lam. seed extract, Evidence-Based Complementary and Alternative Medicine, 2013: 1-4. https://doi.org/10.1155/2013/835854

SARRIS, J., MCINTYRE, E. \& CAMFIELD, D. A. (2013) Plant-based medicines for anxiety disorders, part 1: A review of preclinical studies, CNS Drugs, 27(3):207-219. https://doi.org/10.1007/s40263-013-0044-3

SASSOUI, D., SERIDI, R., AZIN, K. \& USAI, M. (2015) Evaluation of phytochemical constituents by GCMS and antidepressant activity of Peganum harmala L. seeds extract, Asian Pacific Journal of Tropical Disease, 5(12): 971-974. https://doi.org/10.1016/S22221808(15)60967-7

SELVI, P. T., SENTHIL KUMAR, M., RAJESH, R. \& KATHIRAVAN, T. (2012) Antidepressant activity of ethanolic extract of leaves of Centella asiatica Linn by in vivo method, Asian Journal of Research in Pharmaceutical Sciences, 2(2): 76-79.

SHARMEN, F., MANNAN, A., RAHMAN, M. M., MAU, C., UDDIN, M. E. \& ABU AHMED, A. M. (2014) Investigation of in vivo neuropharmacological effect of Alpinia nigra leaf extract, Asian Pacific Journal of Tropical Biomedicine, 4(2): 137-142. https://doi.org/10.1016/S2221 $-1691(14) 60222-7$

SHIN, I. -M., SON, S. U., PARK, H., KIM, Y., PARK, S. H., KELLEY SWANBERG, K., et al. (2014) Preclinical evidence of rapid- onset antidepressant-like effect in Radix polygalae extract, PLoS ONE, 9(2): e88617. https://doi.org/10.1371/journal.pone.0088617

SON, H., JUNG, S., SHIN, J. H., KANG, M. J. \& KIM, H. J. (2018) Anti-stress and antidepressive effects of spinach extracts on a chronic stress-induced depression mouse model through lowering blood corticosterone and increasing brain glutamate and glutamine levels, Journal of Clinical Medicine, 7(11): 406. https://doi.org/10.3390/jcm7110406

Malay J Pharm Sci, Vol. 19, No. 1 (2021): 77-96 
SUN, T., LIU, B. \& LI, P. (2015) Nerve protective effect of Asiaticoside against ischemiahypoxia in cultured rat cortex neurons, Medical Science Monitor, 21: 3036-3041. https://doi.org/10.12659/MSM.894024

SWOGGER, M. T., ELAINE, H., FIRE, E., EARTH, E., NICOLE, T., KAILA, Y., et al. (2015) Experiences of Kratom users: Qualitative analysis, Journal of Psychoactive Drugs, 47(5): 360-367. https://doi.org/10.1080/02791072.2015.1096434

TANASAWET, S., BOONRUAMKAEW, P., SUKKETSIRI, W. \& CHONPATHOMPIKUNLERT, P. (2017) Anxiolytic and free radical scavenging potential of Chinese celery (Apium graveolens) extract in mice, Asian Pacific Journal of Tropical Biomedicine, 7(1): 20-26. https://doi.org/10.1016/j.apjtb.2016.11.003

TARIQ, A., MUSSARAT, S. \& ADNAN, M. (2015) Review on ethnomedicinal, phytochemical and pharmacological evidence of Himalayan anticancer plants, Journal of Ethnopharmacology, 164: 96-119. https://doi.org/10.1016/j.jep.2015.02.003

TIWARI, P., VERMA, R., AHIRWAR, D., CHANDY, A., \& DWIVEDI, S. (2014) Evaluation of anxiolytic effect of Syzygium aromaticum: A traditional herb of India, Asian Pacific Journal of Tropical Disease, 4(Suppl 1), 77-80. https://doi.org/10.1016/S2222-1808(14)60418-7

TROPICOS.ORG. MISSOURI BOTANICAL GARDEN. (2021) Tropicos, connecting the world to botanical data since 1982. http://www.tropicos.org

VIJUSHA, K. K. S., RAJANI, M., HEMAMALINI, A. \& SUNDARI, E. G. R. (2013) Screening of behavioural, muscle co-ordination \& anxiolytic activities of methanolic extract of Tabebuia rosea (Bertol), Asian Journal of Pharmaceutical and Clinical Research, 6(Suppl 5): 4-7.

WANASUNTRONWONG, A., TANTISIRA, M. H., TANTISIRA, B. \& WATANABE, H. (2012) Anxiolytic effects of standardised extract of Centella asiatica (ECa 233) after chronic immobilisation stress in mice, Journal of Ethnopharmacology, 143(2): 579-585. https://doi.org/10.1016/j.jep.2012.07.010

WANG, Y., DAN, Y., YANG, D., HU, Y., ZHANG, L., ZHANG, C., et al. (2014) The genus Anemarrhena Bunge: A review on ethnopharmacology, phytochemistry and pharmacology, Journal of Ethnopharmacology, 153(1): 42-60. https://doi.org/10.1016/j.jep.2014.02.013

WANG, Y., TING, H., YU, Z., CHENG-J, Z., QIAN-L, M., KHALID, R., et al. (2010) Antidepressant properties of bioactive fractions from the extract of Crocus sativus L., Journal of Natural Medicine, 64: 24-30. https://doi.org/10.1007/s11418-009-0360-6

XIE, H., YAN, M. -C., JIN, D., LIU, J. -J., YU, M., DONG, D., et al. (2011) Studies on antidepressant and antinociceptive effects of ethyl acetate extract from Piper laetispicum and structure-activity relationship of its amide alkaloids, Fitoterapia, 82(7): 1086-1092. https://doi.org/10.1016/j.fitote.2011.07.006 
YENNURAJALINGAM, S., REDDY, A., TANNIR, N. M., GARY, B. C., RICHARD, T. L. \& GABRIEL, L. (2015) High-dose Asian ginseng (Panax ginseng) for cancer-related fatigue: A preliminary report, Integrative Cancer Therapies, 14(5): 419-427. https://doi.org/ $10.1177 / 1534735415580676$

YI, L. -T., LI, J., LI, H. -C., ZHOU, Y., SU B, -F., YANG, K. -F., et al. (2012) Ethanol extract from Hemerocallis citrina attenuate the decreases of brain-derived neurotropic factor, TrkB levels in rat induced by corticosterone administration, Journal of Ethnopharmacology, 2012: 328-334. https://doi.org/10.1016/j.jep.2012.09.016

ZENK, M. H. \& JUENGER, M. (2007) Evolution and current status of the phytochemistry of nitrogenous compounds, Phytochemistry, 68: 2757-2772. https://doi.org/10.1016/ j.phytochem.2007.07.009

ZHAO, Z., WANG, W., GUO, H. \& ZHOU, D. (2008) Antidepressant-like effect of liquiritin from Glycyrrhiza uralensis in chronic variable stress induced depression model rats, Behavioural Brain Research, 194(1): 108-113. https://doi.org/10.1016/j.bbr.2008.06.030

ZHENG, M., FAN, Y., SHI, D. \& LIU, C. (2013) Antidepressant-like effect of flavonoids extracted from Apocynum venetum leaves on brain monoamine levels and dopaminergic system, Journal of Ethnopharmacology, 147: 108-113. https://doi.org/10.1016/j.jep .2013.02.015

ZHOU, Z., YIN, W., YANG, Y., HE, C. \& LI, X. (2016) New iridoid glycosides with antidepressant activity isolated from Cyperus rotundus, Chemistry Pharmaceutical Bulletin, 64(1): 73-77. https://doi.org/10.1248/cpb.c15-00686 